\title{
Pollen morphology and availability of pollen and stigma in Syzygium (Myrtaceae)
}

\author{
Guilherme Nacata $^{1}$, Talita Kely Belonsi ${ }^{2}$, Eduardo Custódio Gasparino ${ }^{3}$, Renata Aparecida de Andrade ${ }^{4}$
}

Abstract - The present study aimed to describe the pollen morphology in three species of Syzygium, to test pollen availability and stigma receptivity. The pollen was analyzed by light and scanning microscopy to show the detailed ornamentation of the pollen grains. Pollen availability was measured according to two protocols. Stigmatic receptivity was tested at different stages of flower development. There are differences among the pollen morphology for the species studied; when the polar and equatorial diameters are measured in the equatorial view of the pollen grains, it is observed that $S$. jambos is the largest species concerning the two values of the diameters, $S$. malaccense is the smallest species and $S$. aqueum, the largest species in relation to the polar diameter in the equatorial view. For the equatorial diameter in equatorial view, S. aqueum showed the smallest diameters and S. malaccense, the major diameters, but the two species overlap in the values of the measured diameters. There are variations in the number of apertures in the pollen grains. Alexander's stain is more sensitive to estimate pollen availability and the species $S$. aqueum and $S$. jambos have the same schedules of pollen availability and stigma receptivity.

Index terms: Exotic fruit tree, Palynology, Pollen grains, Stigma, Syzygium.

\section{Morfologia polínica e viabilidade do pólen e estigma em Syzygium (Myrtaceae)}

\begin{abstract}
Corresponding author: guilhermenacata@usp.br

Received: April 22, 2019 Accepted: October 09, 2019

Copyright: All the contents of this journal, except where otherwise noted, is licensed under a Creative Commons Attribution License.
\end{abstract}

\section{(cc) $\mathrm{EY}$}

Resumo - O presente estudo teve como objetivo descrever a morfologia polínica de três espécies de jambeiro e testar disponibilidade de pólen e receptividade de estigma. Foram analisados os grãos de pólen de Syzygium aqueum, Syzygium jambos e Syzygium malaccense. Realizou-se a leitura do material por microscopia de luz e varredura, a fim de evidenciar a ornamentação detalhada dos grãos de pólen. A viabilidade polínica foi medida de acordo com dois protocolos. A receptividade estigmática foi testada em diferentes estádios de desenvolvimento da flor. Existem diferenças entre a morfologia polínica para as espécies estudadas, medindo os diâmetros polares e equatoriais, em vista equatorial, dos grãos de pólen, observa-se que o $S$. jambos é a espécie de maior tamanho nos dois valores dos diâmetros; $S$. malaccense é a espécie de menor tamanho; $S$. aqueum é a espécie de maior tamanho em relação ao diâmetro polar em vista equatorial. Já em diâmetro equatorial em vista equatorial, $S$. aqueum apresentou os menores diâmetros, e $S$. malaccense, os maiores diâmetros, porém as duas espécies sobrepõem-se nos valores dos diâmetros medidos. Existem variações na quantidade de aberturas nos grãos de pólen. O teste de alexander é mais sensível para avaliação de grãos de pólen, e as espécies $S$. aqueum e $S$. jambos têm os mesmos horários de disponibilidade de pólen e de receptividade estigmática.

Termos para indexação: Estigma, Frutífera exótica, Palinologia, grãos de polén, Syzygium.

${ }^{1}$ Eng. Agr., Aluno de Doutorado em Agronomia (Fitotecnia), Universidade de São Paulo, Escola Superior de Agricultura "Luís de Queiroz". Piracicaba-SP. Brasil. E-mail: guilhermenacata@usp.br(ORCID 0000-0002-7797-9267)

${ }^{2}$ Bióloga, Aluna de Doutorado em Biologia Comparada, Universidade de São Paulo. Ribeirão Preto. E-mail: talitakb@usp.br (ORCID 0000-0003-2586-4238)

${ }^{3}$ Biólogo, Prof. Prof. Assist. Dr., Universidade Estadual Paulista "Júlio de mesquita Filho", Faculdade de Ciências Agrárias e Veterinárias, Departamento de Biologia Aplicada à Agropecuária. Jaboticabal-SP. E-mail: eduardo.gasparino@unesp.br(ORCID 0000-0001-6078-7341)

${ }^{4}$ Eng. Agr., Prof. Assist. Dr., Universidade Estadual Paulista “Júlio de Mesquita Filho", Faculdade de Ciências Agrárias e Veterinárias, Departamento de Produção Vegetal. Jaboticabal-SP. E-mail: renata.andrade@unesp.br (0RCID 0000-0002-9795-7049) 


\section{Introduction}

Myrtaceae is a pantropical family which presents around 145 genera and 4600 species, as the second largest family of the order Myrtales (SIMPSON, 2012; APG IV, 2016). With a broad diversity of habitats, it is represented in Brazil by around 23 genera and 1030 species (Eugenia in Flora do Brasil 2020 under construction).

The genus Syzygium is placed inside Myrtaceae, and is the largest genus of the family, with 1200 species (JUDD et al., 2009). Inside the genus, the following species are prominent: malay apple (Syzygium malaccense (L.) Meer. \& L.M.Perry); water apple (Syzygium aqueum (Burm.f.) Alston and rose apple (Syzygium jambos (L.) Alston). These three Syzygium species have the Asian Continent as their center of origin, being found in the whole pantropical range and, in Brazil, in the regions of Amazonia, Cerrado, Pantanal and Atlantic Forest, with great commercialization in the regions North and Northeast (DONADIO, 1998; ALMEIDA, 2008; AUGUSTA et al., 2010).

It is crucial to understand the morphophysiological traits of plant species and to have a perception on the behavior and needs for an exploration in commercial level. To achieve this success, the reproductive process of the plant species is greatly important. The study on pollen availability provides an important characteristic for gene flow analyses in plant breeding programs, besides being used in ecological, taxonomic and palynological studies (FRESCURA et al., 2012). According to Soh and Parnell (2015), in a study report on the morphology of the genus Syzygium, they comment that there is a difficulty in differentiating the species by the pollen grains and the malay, water and rose apples present the biggest pollen grains when compared to the other species of the same genus.

The knowledge of the flowering patterns and pollination mechanisms of a species can be used as a basis to understand the reproductive process, granting information for the maximum exploration and control in fruit production (FISH; NOGUEIRA JUNIOR; MANTOVANI, 2000).

"In the available literature there is a lack in studies comparing and characterizing morphologically the pollen grains of S. Malaccense, S. jambos and S. Aqueum." Therefore, this work has the purpose of describing the pollen morphology of each species, searching for characters that might differentiate them, and assessing pollen availability and stigma receptivity among species that share the same flowering season, in order to understand their pollination mechanism (behavior/ schedule of the pollinator agent).

\section{Material and methods}

\section{Morphology of the pollen grain}

Studied species and sample collection: the pollen grains of three Syzygium species were analyzed: Syzygium aqueum (Burm.f.) Alston, Syzygium jambos (L.) Alston and Syzygium malaccense (L) Meer \& Perry. The materials were collected from trees present in the College of Agrarian and Veterinary Sciences, UNESP, Jaboticabal Campus. The material was deposited in the Herbarium JABU, from the same institution.

Material Collected: Syzygium aqueum (Burm.f.) Alston: BRASIL. São Paulo: Jaboticabal, FCAV. Bellonzi, T.K. \& Nacata, G. s/no (JABU); Syzygium jambos (L.) Alston BRASIL. São Paulo: Jaboticabal, FCAV. Bellonzi, T.K. \& Nacata, G. s/n ${ }^{\circ}$ (JABU); Syzygium malaccense (L) Meer \& Perry. BRASIL. São Paulo: Jaboticabal, FCAV. Bellonzi, T.K. \& Nacata, G. s/nº (JABU).

Processing for the Light Microscopy: for pollen morphology analysis, we used of each specimen at least two flowers with fertile anthers, close to anthesis, to obtain a significant sample. For the analysis by optic microscopy, the pollen grains were acetolysed using the classic acetolysis technique (ERDTMAN, 1960), following the modifications proposed by Melhem et al. (2003). The pollen material remained in the acetolytic mixture for one minute and thirty seconds. Subsequently, the material was fixed between slides and coverslips with glycerine-gelatin and sealed with molten paraffin.

The slides obtained were incorporated to the Pollen Collection of the Departmento de Biologia Aplicada à Agropecuária, Universidade Estadual Paulista, Faculdade de Ciências Agrárias e Veterinárias, Jaboticabal (FCAV), as control material.

The pollen grains prepared for the light microscope analysis had their diameters randomly measured ( $\mathrm{n}=$ 25), in the period of one week (MELHEM; MATOS 1972, SALGADO-LABOURIAU 1973). For the other characters, such as the endoapertures, and colpus width index, ten measurements were performed.

From the quantitative data obtained, the range of variation of the measurements performed was presented, and a descriptive statistic was conducted, where the arithmetic mean (x), the standard deviation of the mean (sx), the standard deviation of the sample (s), the coefficient of variability (CV) and the confidence interval at $95 \%(\mathrm{CI})$ were calculated. The comparisons of the means among each of the studied species were performed by analysis of variance, followed by the Tukey's test (SAS, version 9.0), whose data were presented in graphs using the statistic package MINITAB 10.3.

Record and descriptions of the pollen characteristics: for the documentation of the pollen characters observed and measured under light microscopy, photomicrographs were performed with the help of an 
optic microscope (model Leica IM50) coupled to a video camera and a microcomputer. From these images, the boards for the illustration of the pollen grains analyzed were developed.

The pollen descriptions and the terminologies adopted were based on the glossaries of Barth and Melhem (1988) and Punt et al. (2007) and the classes of the colpus width index followed Gasparino; Cruz-Barros; Chautems, (2013).

Analysis of Scanning Electron Microscopy (SEM): in order to evidence the detailed ornamentation of the exine of the pollen grains, they were photographed using the scanning technique. For this procedure, the methodology described in Melhem et al. (2003), for acetolysed and non-acetolysed pollen grains, was used.

After the preparation of the pollen grains for the SEM analysis, the samples were deposited on stubs, dried, metallized by evaporation of gold under high vacuum and analyzed under electronic microscope.

\section{Pollen and stigma availability}

The experiment used the same materials and the same structure adopted for the morphology of the pollen grains; nevertheless, for this evaluation, only materials from Syzygium jambos and S. aqueum were used. The pollen grains of $S$. malaccense we're not used because the plants did not flower in the same period as the two species listed.

Pollen availability was measured according to two protocols (acetocarmine and Alexander's stain using methods of dyes by the identification of the aborted grains (Alexander, 1980). We used flowers in anthesis at different times: at: 8:00, 12:00 am and 2:00, 4:00 pm.

Each treatment was employed for the evaluation of pollen availability, applied to six anthers which were divided into two histological slides (three anthers per slides), they were subsequently macerated and stained with a drop of $2 \%$ acetocarmine and Acetic Alexander, totalizing four slides evaluated. Subsequently, they were transferred to a light microscope with lens Coleman 40x, where it was possible to count the pollen grains, with the grains which got stained classified as viable and the unstained grains, non-viable. Ten fields in each slide were used for the count, totalizing 20 fields analyzed per dye.

The evaluation of stigma receptivity was assayed five flowers at different stages of flower development, from the flower bud to the mature flower (pre-anthesis, anthesis and open flower), using 10 units hydrogen peroxide on the surface of the stigma and observing the reaction, which releases oxygen (ZEISLER, 1938).

Regarding the "in vitro" germination, we used five flowers and two Petri dishes were used per flower, containing the culture medium described by Cheng and Freeling (1976). Three anthers with pollen were distributed on the culture medium, and the dishes were placed in the dark. After 2 hours, approximately, the number of sprouted pollen grains was observed with a stereomicroscope, in ten fields of the dish, in a total of 20 fields. The pollen grains were considered sprouted when presenting pollen tube with length higher than or equal to the pollen grain diameter.

For the experiments of stigma receptivity and "in vitro" germination, the flowers had previously been identified (6:00 hours) and they were evaluated for 12 hours, with an interval of 2 hours each evaluation. For the availability analysis, the results were plotted in a graph, estimating the amount of viable and non-viable pollen grains per slide.

\section{Results and discussion}

\section{Morphology of the pollen grain}

The pollen grains from the three Syzygium species studied are monads, isopolar (Syzygium jambos) or heteropolar ( $S$. aqueum, $S$. malaccense), of small size, varying from oblate ( $S$. malaccense and $S$. jambos) to suboblate ( $S$. aqueum), all species with triangular amb, 3-colporate (S. aqueum, S. malaccense) to 3-(4)- colporate (S. jambos), long and narrow colpus, parassincolporate in both apocolpium, presenting lolongate endoapertures (not evident) (Figures 1) (Tables 1, 2 and 3). Psilate exine and thicker nexine than sexine.

Table 1 - Morphological characterization of the pollen grains of the genus Syzygium. $\mathrm{S}=$ small, $\mathrm{O}=$ oblate, $\mathrm{SO}=$ suboblate, $\mathrm{P} / \mathrm{E}=$ ratio between polar and equatorial diameter. $\mathrm{PSI}=$ psilate. $\mathrm{UNESP} / \mathrm{Jaboticabal}$.

\begin{tabular}{llllll}
\hline Species & Size & $\mathrm{P} / \mathrm{E}$ & Shape & Apertures & Exine \\
\hline Syzygium aqueum & $\mathrm{S}$ & 0.76 & $\mathrm{SO}$ & 3 colporate & Psilate \\
Syzygium malaccense & $\mathrm{S}$ & 0.67 & $\mathrm{O}$ & 3-colporate & Psilate \\
Syzygium jambos & $\mathrm{S}$ & 0.63 & $\mathrm{O}$ & 3(4) colporate & Psilate \\
\hline
\end{tabular}


Table 2 - Measure of the polar and equatorial diameters of the pollen grains of the genus Syzygium. $\mathrm{n}=25 . \mathrm{X}_{\min }=$ the lowest value observed $(\mu \mathrm{m}), \mathrm{X}_{\max }=$ the highest value observed $(\mu \mathrm{m}), x=\operatorname{arithmetic~mean}(\mu \mathrm{m}), s_{x}=$ standard deviation of the mean $(\mu \mathrm{m}), s=$ standard deviation of the sample $(\mu \mathrm{m}), \mathrm{CI}=$ confidence interval at $95 \%(\mu \mathrm{m}), \mathrm{CV}=$ coefficient of variability (\%). UNESP/Jaboticabal.

\begin{tabular}{lclll}
\hline Species & $\left(\mathrm{X}_{\max }-\mathrm{X}_{\min }\right) x \pm s_{x}$ & $\mathrm{~s}$ & $\mathrm{CI}$ & $\mathrm{CV}$ \\
\hline Equatorial Diameter in Polar View & $(12.50-17.50) 15.90 \pm 0.28$ & 1.42 & $(15.31-16.49)$ & 8.49 \\
\hline Syzygium aqueum & $(15.00-22.50) 17.90 \pm 0.37$ & 1.87 & $(17.13-18.67)$ & 10.42 \\
Syzygium malaccense & $(20.51-25.64) 23.79 \pm 0.35$ & 1.74 & $(23.08-24.51)$ & 7.31 \\
Syzygium jambos & $(12.50-17.50) 13.50 \pm 0.29$ & 1.44 & $(12.91-14.09)$ & 10.69 \\
\hline Polar Diameter in Equatorial View & $(10.00-17.50) 12.40 \pm 0.42$ & 2.10 & $(11.53-13.27)$ & 16.95 \\
\hline Syzygium aqueum & $(12.82-17.95) 16.10 \pm 0.38$ & 1.89 & $(15.32-16.88)$ & 11.74 \\
Syzygium malaccense & $\left(\mathrm{X}_{\max }-\mathrm{X}_{\min }\right) x \pm s_{x}$ & $\mathrm{~s}$ & $\mathrm{CI}$ & $\mathrm{CV}$ \\
Syzygium jambos & $(15.00-22.50) 17.80 \pm 0.26$ & 1.31 & $(17.26-18.34)$ & 7.39 \\
\hline Species & $(15.00-22.50) 18.50 \pm 0.41$ & 2.04 & $(17.66-19.54)$ & 11.03 \\
\hline Equatorial Diameter in Equatorial View & $(23.08-28.21) 25.44 \pm 0.33$ & 1.64 & $(24.76-26.11)$ & 6.45 \\
\hline Syzygium aqueum & & & & \\
Syzygium malaccense & & & & \\
\hline Syzygium jambos & & & & \\
\hline
\end{tabular}

Table 3 - Arithmetic mean, in $\mu \mathrm{m}$, of the measures of the pollen grain apertures and exine layers in the genus Syzygium, $\mathrm{n}=10$. Len. $=$ length, Wid. $=$ width. ILC $=$ Colpus width index. *Endoaperture not evidente. $\mathrm{N}=10 . \mathrm{UNESP} /$ Jaboticabal.

\begin{tabular}{|c|c|c|c|c|c|c|c|}
\hline \multirow[b]{2}{*}{ Species } & \multicolumn{2}{|c|}{ Colpus } & \multicolumn{2}{|c|}{ Endoaperture } & \multirow[t]{2}{*}{ Exine } & \multirow[t]{2}{*}{ Sexine } & \multirow[t]{2}{*}{ Nexine } \\
\hline & Wid. & ILC & Len. & Wid. & & & \\
\hline Syzygium aqueum & 1.03 & 15.43 & $*$ & $*$ & 1.57 & 0.66 & 0.91 \\
\hline Syzygium malaccense & 1.19 & 15.04 & $*$ & $*$ & 1.78 & 0.75 & 1.03 \\
\hline Syzygium jambos & 1.28 & 18.58 & 2.32 & 1.99 & 2.25 & 1.04 & 1.21 \\
\hline
\end{tabular}




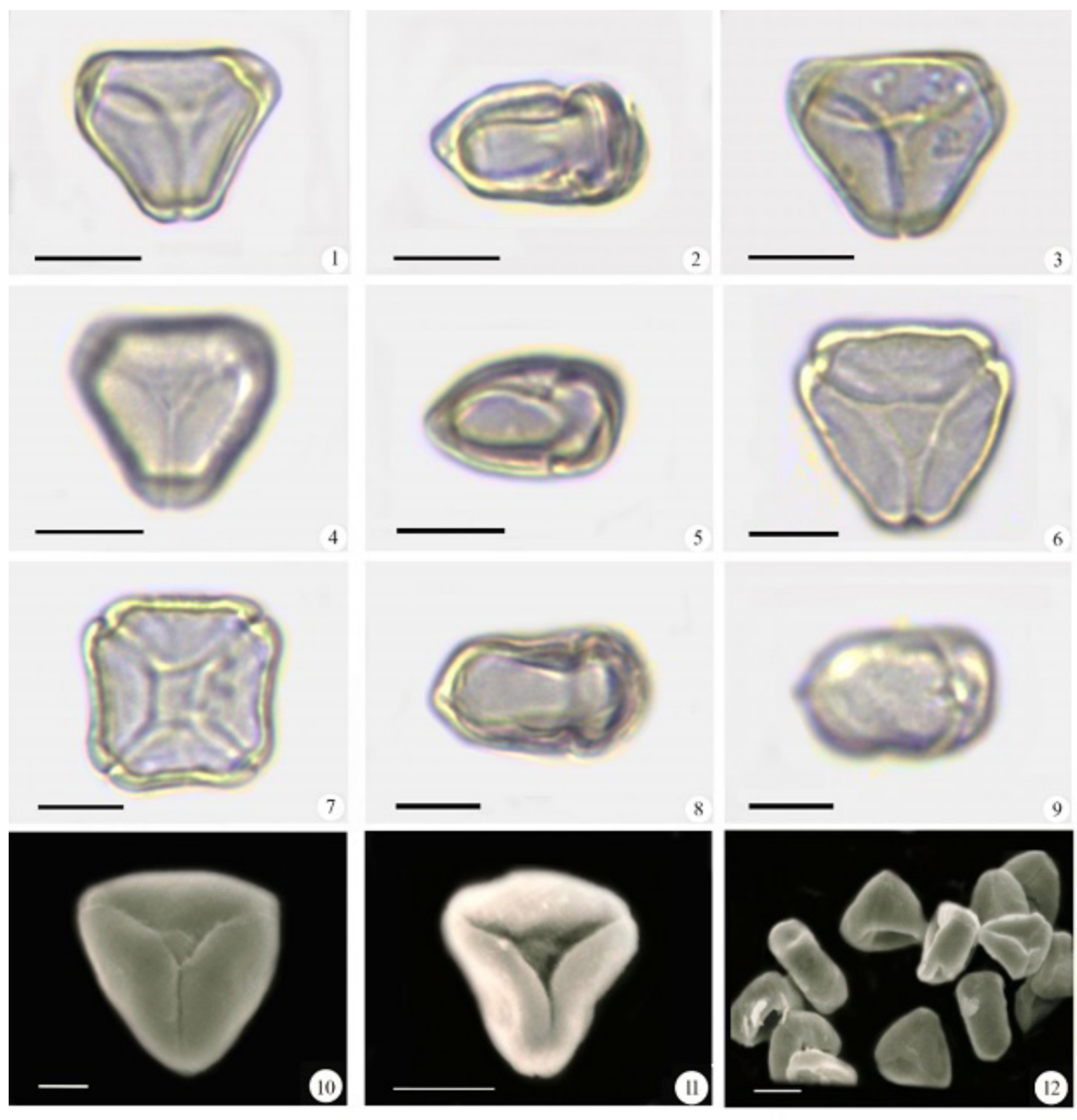

Figure 1 - Photomicrograph of the Syzygium pollen grains. 1-2. S. aqueum (Burm.f.) Alston 1. Polar view. 2. Equatorial view. 3-5. S. malaccense (L.) Merr. \& L. M. Perry. 3-4. Polar view. 5. Equatorial view. 6-9. S. jambos (L.) Alston 6-7. Polar view 7. 4-colporate grain. 8-9 Equatorial view. 9. Lolongate aperture. 10-12 Electromicrography of Syzygium. Scales $=10 \mu \mathrm{m}$. UNESP/Jaboticabal, 2016. Source: Talita Kely Bellonzi.

When the values of mean and confidence interval of the polar and equatorial diameters are analyzed in an equatorial view of the pollen grains from the three Sygyzium species studied here (Figure 2), it is observed that: 

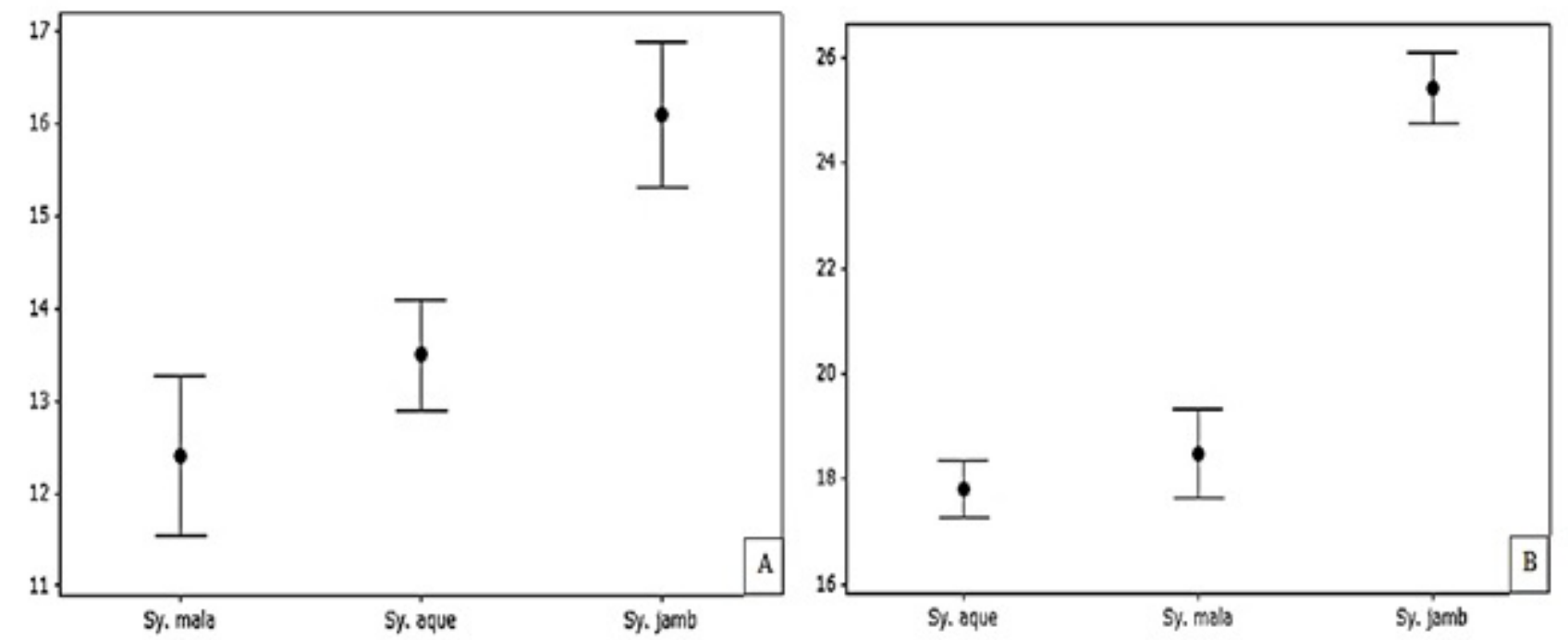

Figure 2- Graphic representation of the mean and the confidence intervals of the mean at $95 \%$ of the measures of Syzygium pollen grains. A: Polar diameter in equatorial view. B: Equatorial diameter in equatorial view. The superior and inferior limites represent the confidence interval, the middle circles represent the arithmetic mean. The values are in $\mu \mathrm{m}$.

a) Syzygium jambos is the species with the highest size in the two values of diameters (Table 2);

b) Syzygium malaccense is the species with the smallest size and $S$. aqueum is the species with the biggest size regarding polar diameter in the equatorial view (Figure 2A). On the other hand, considering the equatorial diameter in equatorial view (Figure 2B), S. aqueum presented the smallest diameters and $S$. malaccense the biggest diameters, but these two species overlap in the values of the diameters measured (Tables 2 and 3 ).

Soh and Parnell (2015) described the morphology of the pollen grains from Syzygium aqueum and S. jambos in a study involving species from Thailand and observed small, isopolar, suboblate and 3-parassincolporate pollen grains for the species mentioned. The present work indicates heteropolar pollen grains for $S$. aqueum and a variation of the number of apertures for $S$. jambos (3-(4)-colporate), a fact which was not observed by Soh and Parnell (2015). This difference in the results probably occurs because of the methodology employed, since the authors did not acetolyse the pollen grains for the analysis.

Thornhill et al. (2012), analyzing pollen morphology for this genus, described small, 3-colporate, parasincolporate pollen grains, with psilate to rugulate or verrucate to scabrate exine. The results are similar to those observed in the present study; however, for the species here analyzed, structures of exine ornamentation were not identified, being classified as psilate.

Still according to Thornhill et al. (2012), the morphology of the Myrtaceae Tribes: Backhousieae, Maleleuceae, Metrosidereae, Osbomieae and Syzygieae is of difficult distinction, observing only the morphology of the pollen grains. In general, Syzygium presents smaller grains when compared to the other genera. The authors also point a variation in the pollen grain shape in species of this genus, and cite that this feature apparently does not have any taxonomic value.

\section{Pollen and stigma availability}

Given the analyses of coloration to estimate Syzygium jambos pollen availability, with the dyes $2 \%$ acetocarmine and Alexander's stain, it is observed that the first presented a higher sensitivity, from a total of 3092 pollen grains evaluated, 1786 were viable (57\%) and 1306 were non-viable (42\%). This assay is based on the coloration of the pollen genetic material in red, but only the viable grains appear stained, whereas the non-viable grains are transparent (PAGLIARINI; POZZOBON, 2004).

With the assay using Alexander's stain, 2048 grains were observed, and from this total 1547 are viable (75\%) and 501 are non-viable (25\%). According to Alexander (1980), this assay allows the distinction between viable and non-viable grains by the differential coloration of the cellulose from the pollen grain cell wall into blue-green and the protoplasms (nucleus) in purple color, enabling the observation of aborted and non-aborted pollen grains, since the material which only presents coloration in the cell wall indicates that there is no genetic material, in other words, they do not have the nucleus.

This technique can also be extrapolated to be used in the identification of hybrid materials, for presenting pollen grains without nucleus or a modified nucleus (CABRAL et al., 2013). 
By the schedules when flower collection was performed and by the two colorimetric assays, it can be said that there is a higher amount and availability of the pollen grains in the morning period (until $80 \%$ ), a drop in the middle of the day and there is a resumption of the percentage of availability at 18 hours (Figure 14).

Given the analyses of coloration to estimate $S$. aqueum pollen availability, with $2 \%$ acetocarmine, 285 pollen grains were observed, and from this total, 139 were viable (48\%) and 146 were non-viable (52\%); for Alexander's stain, 250 pollen grains were analyzed, computing 179 viable (72\%) and 71 non-viable (28\%). Among the assays used, it can be said that Alexander's stain estimated a larger amount of viable pollen grains.

For Baéz; Riveros and Lehnebach (2002), the dye acetocarmine and Alexander's stain, used to indicate pollen availability, only reflect the integrity of the cell structures, such as nucleus and plasma membrane. Alexander (1980) claims that, using Alexander's stain, it is possible to differentiate the aborted from the nonaborted pollen grains, since the last do not possess the nucleus, and only the cellulose contained in the wall will present coloration.

The reaction of the hydrogen produced by cell respiration in contact with the solution guarantees a red coloration to the viable pollen grain, which does not occur in the non-viable ones (SOUZA et al., 2002).
The pollen grain, at the flower aperture, needs to be completely viable and, usually, as time passes, pollen grain availability decreases and reduces its efficiency in fertilization (SOUZA et al., 2002). As the pollen ages, the length of the pollen tube and the percentage of pollination decrease (SCORZA; SHERMAN, 1995; REINHARDT et al., 2006). According to Cheavegatti-Gianotto et al. (2011), the time for reading pollen availability is greatly important, since most of the tropical species are sensitive to temperature and humidity, observing that the first hours of the day are the best for analyzing the maximum availability.

Regarding stigma receptivity, the species Syzygium aqueum is receptible in the whole period analyzed and for $S$. jambos it is only receptible in the afternoon period. According to Dias et al. (2018), stigma receptivity may vary from species to species. Additionally, in breeding programs, the knowledge of the floral stage which presents a receptive stigma is related to the success of the pollination (Figure 3 ).
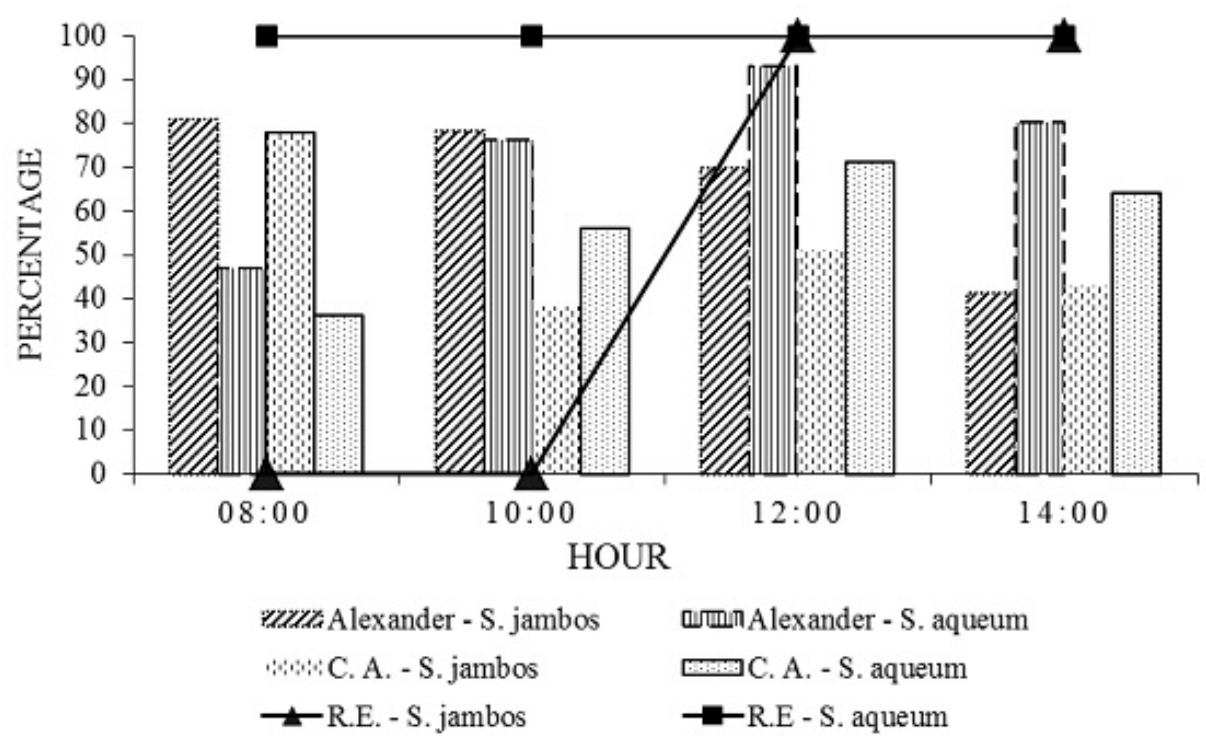

Figure 3- Time variation of the percentage of viable pollen grains by two methods of evaluation: $2 \%$ acetocarmine and Alexander's stain and stigma receptivity of Syzygium aqueum Burm.f. and Syzygium jambos. *C.A.- acetocarmine; R.E - Stigma receptivity. 
The species Syzygium jambos has the highest percentage of viable pollen during the first hours of evaluation and it decreases during the day ("in vitro" germination), resuming the highest availability from 12 hours on after marking the flowers. For S. aqueum, in the first four hours of evaluation, pollen availability is low and there is an increase six hours after marking the plants, and its stigma is receptive during the whole period analyzed, thus indicating that pollination might occur for the whole period evaluated, with the highest pollen availability in the afternoon.

The pollen grains reflect the respiratory activity of the living tissue, with its enzymatic activity related to the ability of germination (DERIN; ETI 1999). According to (Cuchiara; Bobrowski, 2015) the availabilities of viable pollen grains might vary among individuals of the same species and among samples of the same individual. Studies to know morphologically the periods of availability of the male and female organs are indispensable for the practice of plant breeding (VAL et al., 2010; HISTER; TEDESCO, 2016).

\section{Conclusion}

Considering polar diameter and equatorial view, Syzygium jambos is the species with the biggest size in both diameter values, $S$. malaccense is the species with the smallest size and $S$. aqueum is the species with the biggest size. On the other hand, considering the equatorial diameter in equatorial view, S. aqueum presented the smallest diameters and $S$. malaccense, the largest diameters, but the two species overlap in the values of the diameters measured. There are variations in the number of apertures in the pollen grains.

The availability assay indicates that Alexander's stain is more sensitive to estimate pollen availability for Syzygium jambos and S. aqueum and the methodology applied for pollen grain germination was inefficient for the three species analyzed.

The species $S$. jambos and $S$. aqueum have the same schedules of pollen availability and stigma receptivity.

\section{Acknowledgment}

Coordenação de Aperfeiçoamento de Pessoal de Nível Superior - Brasil (CAPES) for project financing. The structure of the Departamento de Biologia Aplicado a Agronomia, FCAV/UNESP and Laboratory of Microscopy of FCAV/UNESP.".

\section{References}

ALEXANDER, M.P. A versatile stain for pollen, fungi, yeast and bacteria. Stain Technology, Baltimore, v.55, p.13-18, 1980.

ALMEIDA, E.J.DE.; TORRECILLAS SCALOPPI, E.M., JESUS, N.D.E.; BENASSI, A.C.; DEVOS GANGA, R.M.; MARTINS, A.B.G. Propagação vegetativa de jambeiro vermelho [Syzygium malaccense (L.) Merr. \& L.M. Perry]. Ciência e Agrotecnologia, Lavras, v.34, p.1658-1663, 2008.

APG IV. An update of the Angiosperm Phylogeny Group Classification for the Orders And Families of flowering plant. Botanical Journal of The Linnean Society, London, v.181, p.1-20, 2016.

AUGUSTA, I.M.; RESENDE, J.M.; BORGES, S.V.; MAIA M.C.A.; COUTO, M.A.P.G. Caracterização física e química da casca e polpa de jambo vermelho (Syzygium malaccensis, (L.) Merryl \& Perry). Ciência e Tecnologia de Alimentos, Campinas, v.30, n.4, p.928-932, 2010.

BAÉZ, P.; RIVEROS, M.; LEHNEBACH, C. Availability and longevity of pollen of Nothofagus species in south Chile. New Zealand Journal of Botany, Wellington, v.40, p.671-678, 2002.

BARTH, O.M.; MELHEM, T.S. Glossário ilustrado de Palinologia. Campinas: Universidade Estadual de Campinas, 1988. p.132-172.

CABRAL, J.C.; ROSSI, A.A.B.; KLEIN, M.E.; VIEIRA, F.S.; GIUSTINA, L.D. Estimativa da viabilidade polínica em acessos de Theobroma cacao L. baseada em testes colorimétricos. Enciclopédia Biosfera, Goiânia, v.9, n.17, p.2780-2788, 2013.

CHEAVEGATTI-GIANOTTO, A., et al. Sugarcane (Saccharum X officinarum): a reference study for the regulation of genetically modified cultivars in Brazil. Tropical Plant Biology, New York, v.4, n.1, p.62-89, 2011.

CHENG, D.S.K.; FREELING, M. Methods of maize pollen germination in vitro, collection storage, and treatment with toxic chemicals: recovery of resistant mutants. Maize Genetics Cooperation Newsletter, Columbia, v.50, p.11-13, 1976.

CUCHIARA, C.C.; DOS ANJOS, S.D.; BOBROWSKI, V.L. Conservação de grãos de pólen de mamoneira a baixas temperaturas. Revista Ceres, Viçosa, MG, v.59, n.1, p.82-87, 2015. 
DERIN, K.; ETI, S. Determination of pollen quality, quantity and effect of cross pollination on the fruit set and quality in the pomegranate. Turkish Journal of Agriculture and Forestry, Tubitak, v.25 p.169-173, 1999.

DIAS, D.L.O.; BRITTO, F.F.; AMARAL, C.L.F.; MAFFEI, E.M.D.; LIBARINO, V.D. Determinação do sistema reprodutivo de parentais para produção de híbridos entre $P$. cincinnata Mast. e $P$. quadrangularis Linn. Cultura Agronômica: Revista de Ciências Agronômicas, Ilha Solteira, v.27, n.4, p.407-423, 2018.

DONADIO, C.D.; NACHTGAL, J.C.; SACRAMENTO, C.K. Frutas exóticas. Jaboticabal: FUNEP, 1998. p.115-118.

ERDTMAN, G. The acetolysis method. A revised description. Svensk Botanisk Tidskrift, Suécia, v.54, p.561-564, 1960.

FISCH, S.T.V.; NOGUEIRA JUNIOR, L.R.; MANTOVANI, W. Fenologia reprodutiva de Euterpe edulis Mart. na Mata Atlântica (Reserva Ecológica do Trabiju, Pindamonhangaba-SP). Revista Biociências, Taubaté v.6, n.2, p.31-37, 2000.

FRESCURA, V.D.S.; HAYWOOD D.L.ISCOTTI, T.; CANTODOROW, S.B.T. Brief Note Pollen availability of Polygala paniculata L. (Polygalaceae) using different staining methods. Biocell, Argentina, v.36, n.3, p.143145, 2012.

GASPARINO, E.C.; CRUZ-BARROS, M.A.V.; CHAUTEMS, A. Pollen morphology in brazilian species of Codonanthe (Mart.) Hanst. and Nematanthus Schrader (Gesneriaceae). Grana, Abingdon, v.52, p.258-274, 2013.

HISTER C.A.L.; TEDESCO S.B. Estimativa da viabilidade polínica de araçazeiro (Psidium cattleianum Sabine) através de distintos métodos de coloração. Revista Brasileira. de Plantas Medicinais, Botucatu, v.18, n.1, p.135-141, 2016.

JUDD, W.S.; CAMPBELL, C.S.; KELLONG, E.A.; STEVENS, P.F.; DONOGHUE, M.J. Plant systematics: a phylogenetic approach. $3^{\text {rd }}$ ed. Massachusetts: Sinauer Associates, 2009. 625 p.
MELHEM, T.S.; CRUZ BARROS, M.D.; CORRÊA, A.D.S.; MAKINO WATANABE, H.; SILVESTRE CAPELATO, M.S.F.; GONCALVES ESTEVES, V.L. Variabilidade polínica em plantas de Campos do Jordão (São Paulo, Brasil). Boletim do Instituto de Botânica de São Paulo, São Paulo, v.16, p.1-104, 2003.

MELHEM, T.S.; MATOS, M.E.R. Variabilidade de forma dos grãos de pólen de Eriope crassipes Benth. Labiatae. Hoehnea, São Paulo, v.2, p.1-10, 1972.

PAGLIARINI M.S.; POZZOBON M.T. Meiose em vegetais: um enfoque para a caracterização de germoplasma. In: CURSO DE CITOGENÉTICA APLICADA A RECURSOS VEGETAIS, 2., 2004, Brasília. Anais [...] Brasília, DF: EMBRAPA, 2004. p.86.

PUNT, W.; HOEN, P.P.; BLACKMORE, S.; NILSSON, S.; LE THOMAS, A. Glossary of pollen and spore terminology. Review of Palaeobotany and Palynology, New York, v.143 p.1-81, 2007.

REINHARDT, E.; SCOTT, J.; GRAY, K.; KEANE, R. Estomating canopy fuel characteristics in five conifer stands in the western United States using tree and stand measurements. Canadian Journal of Forest Research, Ottawa, v.36, p.2803-2814, 2006.

SALGADO-LABORIAU, M.L. Contribuição à Palinologia dos cerrados. Rio de Janeiro: Academia Brasileira de Ciências, 1973. 291 p.

SCORZA, R.; SHERMAN, W.B.P. In: JANIK J.; MOORE, J.N. (ed.). Fruit breeding. New York: John \& Sons, 1995. p.325-440.

SIMPSON, M.G. Plant systematics. $2^{\text {nd }}$ ed. New York: Academic Press, 2012. 752 p.

SOH, W.K.; PARNELL, J.A revision of Syzygium Gaertn. (Myrtaceae) in Indochina (Cambodia, Laos and Vietnam). Adansonia, Paris, v.37, n.2, p.179-275, 2015.

SOUZA M.M.; PEREIRA, T.N.S.; MARTINS, E.R. Microsporogênese e microgametogênese associadas ao tamanho do botão floral e da antera e viabilidade polínica em maracujazeiro-amarelo (Passiflora edulis Sims f. flavicarpa degener). Ciência Agrotêcnica, Lavras, v.26, n.6, p.1209-1217, 2002.

THORNHILL, A.H.; HOPE, G.S.; CRAVEN, L.A.; CRISP, M.D. Pollen morphology of the Myrtaceae. Part 
2: tribes Backhousieae, Melaleuceae, Metrosidereae, Osbornieae and Syzygieae. Australian Journal of

Botany, Melbourne, v.60, n.3, p.200-224, 2012.

VAL, A.D.B. do.; MOTOIKE, S.Y.; ALVARENGA, E.M.; CECON, P.R. Quebra de dormência de sementes da videira cv.niágara rosada sem estratificaçao. Revista Ceres, Viçosa, MG, v.57, n.2, p.234-238, 2010.

ZEISLER, M. Über die Abgrenzung der eigentlichen

Narbenfläche mit Hilfe von Reaktionen. Beihefte zum
Botanisches Zentralblatta, Berlin, v.58, p.308-318, 1938. 